\title{
Resilience and resistance: powers help phytoplankton to keep spatial heterogeneity during long-term intermittent water diversion
}

Haiyan Pei ( $\square$ haiyanhup@126.com )

Fudan University

Shasha Zhang

Shandong University

Hangzhou Xu

Shandong University

Jielin Wei

Shandong university

Qian Li

Xu'zhou Department of Hydrology and Water Resources Survey Office

\section{Qing Yan}

Huai'an Department of Hydrology and Water Resources Survey Office

\section{Article}

Keywords: Water diversion project, Phytoplankton community composition, Structure stability, Resilience, Long-term monitoring

Posted Date: October 21st, 2021

DOI: https://doi.org/10.21203/rs.3.rs-999849/v1

License: @ (1) This work is licensed under a Creative Commons Attribution 4.0 International License. Read Full License 


\section{Abstract}

How phytoplankton respond to changes in water resource allocations, and whether water diversion cause phytoplankton homogenization remain no incontestable conclusion. Herein the changing rules of phytoplankton communities faced to water diversion were unveiled based on long-term (2011-2019) time-series observation and analysis of algae data of three regulating lakes on the eastern route of the South-to-North Water Diversion Project in China. We found that phytoplankton composition had dramatic differences before and after water transfer; however, after long-term planned water diversion the algal structure especially for abundant species - gradually became similar to that found in 2014 , revealing the community structure was changed by water mixing, and reverted slowly to the initial state after water diversion. Phytoplankton communities exhibited greater fragility when they firstly experienced human-mediated disturbance, while gradually adapted to more interferences and obtained stronger stability. More importantly, we found that the community composition had no homogenization across three lakes after water diversion and resistance and recovery are underlying mechanisms to maintain the community heterogeneity and stability. Moreover, the altered phytoplankton communities in round lakes re-established stable states, while strip-shaped Nansi Lake not, reflecting the strip-shaped lake had slower response and less resilience to the disturbance than the round lakes.

\section{Main}

Freshwater scarcity is increasingly perceived as a global systemic risk ${ }^{1,2}$. At present, about two-thirds of the global population (4.0 billion people) live under conditions of severe water scarcity for at least 1 month of the year and half a billion people face severe water scarcity all year round ${ }^{2-4}$. If action isn't taken, as many as 7 billion people in 60 countries could face water scarcity by $2050^{5}$. In addition, regional water resource shortages are also a big problem because of the uneven temporal and spatial distribution of water resources, besides the water scarcity ${ }^{6}$. More than two billion people live in highly water-stressed areas because of the uneven distribution of freshwater resources in time and space ${ }^{7}$.

To alleviate water shortage issues in arid regions and uneven distribution problems, and to promote social and economic development, numerous water transfer projects have been launched in both developed and developing countries and regions ${ }^{8}$, including the South-to-North Water Transfer Scheme - the world's longest and largest water diversion project, with a planned 45 billion $\mathrm{m}^{3}$ of annual water transfer in China ${ }^{6}$ - as well as the California Water Plan, the Texas Water Plan, and the North-to-South Water Transfer project in the USA ${ }^{9}$. Water importation is intended to provide water for areas of scarcity by transfer from areas of surplus as a solution to water supply problems of those arid areas ${ }^{9}$. These water diversion projects do solve the problem of water shortage and uneven distribution to a certain extent, but the fundamental concern of whether the water diversion projects ruinously affect the aquatic ecological environment is still not well understood.

Water quality is a major issue for operation of water diversion projects, because it is related to the health and safety of inhabitants. While connecting and allocating rivers, lakes, reservoirs and other water resources for human use, hydraulic projects make the water quality issues faced by human beings more intricate than ever before ${ }^{10}$. The controversies and studies about the water quality after the construction of those projects are continuing, and there is still no consensus answer to the question of whether water diversion projects degrade or improve the water environment ${ }^{10}$. On the one hand, water diversion is being increasingly applied to alleviate water pollution and has improved water quality in many water bodies ${ }^{11}$, and the water quality status had been steadily maintained at an "excellent" level after the water transfer ${ }^{10}$. Yet other studies showed that water diversion projects have focused largely on engineering measures related to water quantity, while ignoring the water quality, and so a large amount of poor quality water was diverted that caused the deterioration of water bodies ${ }^{6,12}$. At present this is of particular concern in assessing the effect of water diversion on water quality and the water environment, although studies that document the impact have been limited by a lack of long-term observations and low sampling frequency ${ }^{10,13}$. Meanwhile, there is no systematic research on water quality variation before and after water diversion, or the consequences of long-term water diversion on fundamental phytoplankton community.

Phytoplankton, the foundation of aquatic food webs, are highly diverse in their taxonomy and functional traits ${ }^{14-15}$. They are often the principal autotrophs, supplying organic carbon and oxygen to the system ${ }^{16-17}$. However, phytoplankton exhibit particular sensitivity to changes within aquatic environments ${ }^{18}$. A water diversion project disturbs the water environment by transposing 
water between isolated water bodies without regard for biogeography or aquatic biodiversity, and will lead to a massive introduction of distinct biodiversity in lakes, bio-invasion of lakes, and biotic homogenization across lakes ${ }^{12}$. On the other hand, the projects could decrease the frequency of algal blooms by mixture and dilution of water bodies ${ }^{19}$. Furthermore, phytoplankton contain both abundant and rare species: the rare sub-communities could be inert in one specific environment ${ }^{20,21}$, but responses which turn those species into abundant taxa quickly occur upon changing the water environment ${ }^{22-23}$.

Up to now, many studies designed to test relationships between community composition and environment regime have been performed through laboratory or small-scale field experiments, leading to persistent criticism that the experiments do not accurately capture the real ecosystem consequences of water environment changes ${ }^{24}$. In addition, scientists globally pay increasing attention to the ecological consequences in order to identify the influence of water diversion projects. But as yet there have been few studies revealing the impact of a water diversion project on entire phytoplankton communities and the changes among algal species through long-term monitoring, and also few studies revealing whether the community structure could be restored or whether it permanently collapsed under the conditions of long-term water transfer. Given the potential sensitivity of phytoplankton to water mixing, development of research on the impact of water transfer is increasingly urgent.

China's South-to-North Water Diversion Project, which includes eastern, central, and western routes, is a large-scale strategic project to relieve water shortage and sustain economic and social development in northern China (nsbd.mwr.gov.cn). The Eastern Route spans the four largest river basins in China, namely the Yangtze River basin, the Yellow River basin, the Huai River basin, and the Hai River basin ${ }^{25}$, and it is capable of transferring 14.8 billion $\mathrm{m}^{3}$ of water annually from the Yangtze River to northern China by a complex hydraulic system of interconnected lakes, rivers and canals ${ }^{26}$. Meanwhile, the strict water quality management measures imposed by the government guarantee that there are no big worries about the deterioration of water quality. The water quality index indicated an overall "Good" water quality with an improving trend from upstream to downstream lakes located along the eastern route of the South-to-North Water Diversion Project ${ }^{27}$. Hence the main concerns about water diversion lie in aquatic biodiversity degradation or bio-invasion. Aquatic plants (alligator weed, water hyacinth, and water lettuce) and fish (e.g. Tridentiger bifasciatus) were verified to be able to expand their ranges northward and have caused biological invasion, thereby promoting a potential biotic homogenization between the lakes ${ }^{28-29}$. Up to now there has been surprisingly little research on the bio-invasion of phytoplankton, especially on the eastern route of the South-to-North Water Diversion Project.

Herein we empirically identified the factors driving the abundant and rare species in phytoplankton communities under long-term water transfer conditions, and also uncovered the consequences of water diversion projects for the structure and function of phytoplankton communities. These issues were solved using the data on water quality and phytoplankton communities across nine years' monitoring in the main regulating lakes located on the eastern route of the South-to-North Water Diversion Project in China. The main impounded lakes on that route include Hongze, Luoma, Nansi and Dongping lakes. Three of those lakes (Luoma, Nansi and Dongping lakes) were selected based on the large annual amount of water diversion; the other lake (Hongze Lake) was not selected, as the amount of water diverted annually through it is relatively small, or even nil, in most monitoring years (Table S1). The monitoring data utilized in this analysis are temporally extensive, which provides the opportunity to assess the phytoplankton composition characteristics, and allows for the determination of factors that may contribute to phytoplankton (abundant or rare species) changes. Furthermore, the data sufficiently support us to answer the controversial question of whether the water diversion has an impact on phytoplankton community stability and to verify whether there is a homogenization of biota between these three lakes based on the phytoplankton data.

\section{Results And Discussion}

\subsection{Changes in phytoplankton density and water quality following water diversion}

Water diversion has the potential to change the phytoplankton community composition ${ }^{12}$ and improve the water quality of eutrophic lakes ${ }^{10}$. Because extraordinary disturbances occurred with the operation of the South-to-North Water Diversion Project in Luoma, Nansi and Dongping lakes since October 2013, phytoplankton communities in the three lakes were affected in various ways. Sharp decreases in algal density, particularly for cyanobacteria, have been shown in 2014 in the three lakes. Thereafter algal density remained almost unchanged during the many years of water diversion in the studied lakes (Fig. 1 and Fig. S1). Comparing

Page $3 / 18$ 
these lakes, after water diversion the algal population decreased more in Nansi and Dongping lakes than in Luoma Lake. The annually averaged total algal density changed from 10.9 and 8.7 million cells/L in Nansi and Dongping lakes before water diversion to respectively 4.5 and 4.1 million cells/L after water diversion, while the annually averaged density of total algae only decreased in 2014, and then slightly increased in Luoma Lake. A possible reason lies in the different concentrations of nutrients in the various lakes: the average concentration of TN after water diversion was greater in Luoma Lake $(1.58 \mathrm{mg} / \mathrm{L})$ than in the other lakes $(0.84 \mathrm{mg} / \mathrm{L}$ in Dongping Lake and $0.91 \mathrm{mg} / \mathrm{L}$ in Nansi Lake) (Fig. 2 and Fig. S2). The other reason could be that Luoma Lake (located in Jiangsu Province) had a more suitable temperature and climatic conditions than the other two lakes, causing the cyanobacteria to have a stronger resistance to interference from water diversion.

The concentration of nutrients decreased after water diversion in the three lakes. The average concentration of TN in Luoma Lake was $2.58 \mathrm{mg} / \mathrm{L}$ before the water transfer, while the concentrations were $1.28 \mathrm{mg} / \mathrm{L}$ in Nansi Lake and $1.92 \mathrm{mg} / \mathrm{L}$ in Dongping Lake. A tremendous decline in the concentrations of TN was observed after the disturbances of South-to-North Water Diversion Project in Luoma Lake (1.59 mg/L), Nansi Lake $(0.92 \mathrm{mg} / \mathrm{L})$ and Dongping Lake $(0.84 \mathrm{mg} / \mathrm{L})$ (Fig. 2 and Fig. S2). Before the water diversion, a higher average concentration of TP was detected in Nansi Lake $(0.08 \mathrm{mg} / \mathrm{L})$ compared with Luoma Lake $(0.03 \mathrm{mg} / \mathrm{L})$ and Dongping Lake $(0.04 \mathrm{mg} / \mathrm{L})$. However, the average concentration of TP tended to be consistent $(0.04 \mathrm{mg} / \mathrm{L})$ across the three lakes for the 6-year period of water importation (Fig. 2 and Fig. S2). The main reasons might be that pollution-control projects and dozens of associated measures were implemented, including sewage diversion projects, sewage treatment plant construction, wetland ecological restoration, and closing down of factories with substandard emissions around the lake ${ }^{30}$.

Phosphorus is needed to maintain cell and membrane structure, energy metabolism, the synthesis and expression of genetic material, and a variety of other metabolic and regulatory processes. A low level of accessible $P$ in the environment can compromise algae, causing decreased growth ${ }^{31}$. Currently, lakes are often said to be primarily phosphorus-limited ${ }^{31}$; however, counter-examples cast doubt in some researchers' minds ${ }^{32}$. Herein we compared TP in the three lakes, the concentrations of TP manifested minor changes, with the average concentration $(0.04 \mathrm{mg} / \mathrm{L})$ always being low in Dongping Lake, while more variation occurred in Nansi Lake before and after water transfer. The phytoplankton density in Dongping Lake was consistent with that in Nansi Lake during the study period, but, on the other hand, the algal density did not change in Luoma Lake, where phosphorus concentration clearly changed in stage two. The relation between TP and algal density in different lakes indicates that phosphorus was not the limiting factor in Luoma and Dongping lakes, which are mesotrophic-eutrophic lakes ${ }^{33}$, which supports the concept that the "phosphorus-limitation paradigm" applies only to oligotrophic lakes.

Nutrient management focused on a single nutrient is likely to result in reductions in multiple nutrients. Thus it is often not possible to credit phytoplankton changes only to control of a single nutrient ${ }^{34}$. Nitrogen $(N)$ and phosphorus $(P)$ are the key nutrients for phytoplankton: the combined effects of $\mathrm{N}$ and $\mathrm{P}$ enrichment have accelerated eutrophication and proliferation of phytoplankton on a global scale, particularly for harmful cyanobacteria ${ }^{35}$. Herein we found that TN and TP quickly decrease in stage one of water diversion, and the algal density also simultaneously reduced in Nansi and Dongping lakes. However, in Luoma Lake a decrease of TN and no great variation of TP occurred, and the phytoplankton exhibited no obvious decrease (Fig. 1-2 and Fig. S1-

S2). Traditional approaches for cyanobacterial control have focused on reducing phosphorus $(P)$ inputs to impaired freshwater systems, based on the fact that excessive $\mathrm{P}$ relative to $\mathrm{N}$ inputs (or low $\mathrm{N}$-to-P ratios) were linked to a tendency for systems to be dominated by cyanobacteria ${ }^{36}$. But our results indicate that reducing both $\mathrm{N}$ and $\mathrm{P}$ in a water body provides the best opportunity to reduce phytoplankton density.

Excessive growth of phytoplankton, particularly in the form of cyanobacterial blooms, has become a growing global problem ${ }^{37-38}$. Many species of cyanobacteria are capable of producing toxic and noxious compounds that degrade water quality and pose a risk to human and aquatic ecosystem health ${ }^{39}$. Previous researchers had found warmer waters to favour the incidence of cyanobacterial blooms in many lakes ${ }^{40}$. However, the average annual water temperature had no practically significant changes in the three lakes during the nine years' monitoring (Fig. 2 and Fig. S2). The cyanobacterial density clearly decreased in Nansi and Dongping lakes, while only weak variation occurred in Luoma Lake. Meanwhile the frequency of cyanobacterial blooms did not increase in the three lakes. Overall the intensity of cyanobacterial blooms in these water-diversion lakes did not increase under the influence of global warming. 


\subsection{Influence of environmental selection on abundant and rare phytoplankton sub-communities}

It has been suggested that rare and abundant taxa of microorganisms may have different roles in natural habitats ${ }^{41}$. Abundant species usually contribute a significant role in the ecosystem and participate in major biogeochemical processes such as carbon flow and processing of nutrients, whereas rare taxa can be regarded as propagule banks and play minor but non-negligible roles $^{41,42}$. A ubiquitous pattern has been observed across ecosystems whereby many species are rare, and a few species are abundant ${ }^{20-21,23-24}$. This pattern is also found in our research: there was no species classified as always abundant in 2015 in Luoma Lake, and the number of conditionally abundant species varied from 1 (0.4\%) in 2018 to 8 (4.0\%) in 2015. Conditionally rare species made up a greater proportion in Luoma Lake, reaching $77.4 \%$ in 2016 , and we found that the fewest conditionally abundant and rare species were identified in 2016, with 47 species (20.1\%), whereas the number of such species peaked at 67 (30\%) in 2019. However, there were no always rare species nor moderately abundant taxa classified in Luoma Lake (Table S2). As far as Nansi Lake is concerned, in 2015 there were 6 (2.8\%) algal species that were considered to be abundant, which was the minimum number, while the maximum number of abundant algal species was 22 (12.0\%), which occurred in 2014. The smallest (116 (68.6\%)) and largest (168 (72.4\%)) numbers of rare species were classified in 2010 and 2017, respectively. The identified numbers and proportions of conditionally abundant and rare taxa were distinct in different years, and no moderately abundant taxa nor always rare taxa were found during the study period in Nansi Lake (Table S3). The number and proportion of abundant species varied from 1 (0.7\%) in 2011 to 10 (6.6\%) in 2019 in Dongping Lake, and no always abundant algae were present in 2010 or 2011 (Table S4). In addition, the number and proportion of rare species varied from 85 (56.3\%) in 2019 to 128 (67.0\%) in 2017. There were fewer conditionally rare taxa in Dongping Lake compared with Luoma and Nansi lakes. Consistent with the results in Luoma and Nansi lakes, the number and proportion of conditionally rare and abundant taxa varied dramatically in different sampling years, and no always rare species nor moderately abundant taxa were identified in Dongping Lake (Table S2- S4).

The rare taxa were observed to be dissimilar and to encompass many more unique species in the three lakes. The rare subcommunities could be inert in one specific environment ${ }^{20-21}$, but may become abundant taxa upon environmental changes ${ }^{22-23}$. The rare species underwent dramatic changes in Luoma, Nansi and Dongping lakes following from the water diversion project. Scenedesmus obtusus var. apiculatus was converted from a rare species in Luoma Lake into abundant taxa following water diversion. Other rare species (Cyclotella meneghiniana, Pedinomonas minor, and Achnanthes exigua) were transformed into abundant algae after water diversion in Nansi Lake. Meanwhile, Chlamydomonas microsphaera and Chlorella ellipsoidea were rare taxa before water diversion in Dongping Lake, but they became abundant species after water transfer.

The effects of water diversion on abundant species variation in the three lakes were similar. The number of abundant algae in the three lakes increased in 2013 and 2014 (Table S2- S4), the reasons for this phenomenon might be the dramatic changes of water quality in the three lakes due to water importation, causing rare species and conditionally abundant and rare taxa to be transformed into abundant algae.

Resistance occurs when some members in a microbial community show high tolerance to environmental disturbances ${ }^{43}$. Chlorella vulgaris, Chroomonas acuta and Synedra acus remained classified as always abundant algae under the pressure of the water diversion project and had stronger environmental tolerance than other abundant species (Table S5- S7). Distinct responses of rare and abundant taxa to disturbances might arise from their different life-history strategies. The number of abundant algae remained subsequently unchanged during stage two, which suggests that the phytoplankton communities - especially for abundant species - had a degree of resilience. After a disturbance, the altered microbial community could rapidly recover to its original state or establish an alternative stable state ${ }^{44-45}$.

Phytoplankton are considered to be an indicator of environmental change and ecosystem state owing to their quick and strong responses to environmental disturbances ${ }^{46}$. At the same time, environmental factors such as temperature, light, or nutrient concentrations are known to affect abundance and activity of microbial taxa ${ }^{47-48}$. We adopted Mantel tests to elucidate the relationship between all, abundant, or rare phytoplankton and environmental factors in the three lakes. Studies have demonstrated that different controlling factors constrain the structures of the rare and abundant sub-communities ${ }^{23}$. Herein we observe statistically significant $(p<0.05)$ positive responses between all or abundant taxa and WT; however, there was no statistically significant relationship detected between rare species and WT (Table 1), which could be ascribed to the fact that these species 
may have different growth and activity and thus respond differently to the environmental variable. The result differed from a previous report that temperature showed the strongest correlation with rare species, which is mainly because diatom blooms occurred in the previously studied water body ${ }^{49}$. In addition, phytoplankton had different responses to $\mathrm{pH}$, transparency, $\mathrm{DO}, \mathrm{COD}_{\mathrm{Mn}}$ and TP in the three lakes (Table 1), which are related to the environment of the respective lake itself.

\subsection{Reestablishment and stability of the phytoplankton community structure}

Phytoplankton enable fast responses to abrupt water fluctuation in lakes, and phytoplankton community composition stability and diversity could rapidly change $\mathrm{e}^{14}$. Naselli-Flores and Barone (2000) ${ }^{50}$ reported that the unique hydraulic regimes, rather than nutrient availability, were the main factors affecting the algal community structure in lakes characterized by apparent water mixing. Additionally, some long-term field data for a shallow floodplain lake indicated the relevance of water fluctuations in driving the shift from a state dominated by free-floating plants to a state dominated by phytoplankton ${ }^{51}$.

When the stability of the networks was assessed by calculating the ratio between density (D) and clustering coefficient (transitivity, T) of the network ${ }^{53}$, the values of $\mathrm{D} / \mathrm{T}$ were smaller during non-water-diversion months than water-diversion months, which meant the stability of the algal community structure composition was greater (Fig. 3 and Table S8). Herein it is apparent that there was more stability in non-water-diversion months than in water-diversion months, and the water diversion project acted as an external disturbance to the algal communities of the receiving lakes and, as such, the project was able to directly influence the stability of the phytoplankton community structure.

In addition, co-occurrence networks were constructed in every year depending on whether or not water was transferred. The value of D/T was lower in non-water-diversion months than in water-diversion months during the period of 2013-2016 in Luoma Lake, while the opposite result occurred in 2017-2019 (Fig. S3, Table S9). Moreover, in Dongping Lake D/T was lower in non-waterdiversion months than during water-diversion months from 2014 to 2016, while similar D/T values were calculated for non-waterdiversion months and water-diversion months during 2017-2019 (Fig. S5, Table S11). However, in Nansi Lake the value of D/T was always lower in non-water-diversion months than during water-diversion months (Fig. S4, Table S10). Hence we classified different water diversion phases: before water diversion (2011-2013), stage one of water transfer (2014-2016), and stage two of water importation (2017-2019).

The stability of the algal communities in Luoma and Dongping lakes weakened during phase one of water transfer, while there were no stability changes in Nansi Lake. As the long-term planned water diversion continued the stability in Luoma and Dongping lakes recovered, whilst it decreased in Nansi Lake (Fig. 4 and Fig. S6). The difference in stability changes was mainly caused by different lakes' morphologies: Luoma and Dongping lakes are nearly circular lakes, but Nansi Lake is shaped like a ribbon and behaves more like a river (Fig. S7); another reason could be that the number of rivers flowing into these lakes are different -only one main river (Dawenhe River) flows into Dongping Lake and two main rivers (Yi River and Zhong Canal) flow into Luoma Lake, while 53 rivers flow into Nansi Lake, so that more disturbed locations existed in Nansi Lake than the other studied lakes.

Some systems may respond smoothly to environmental changes, whereas others may show threshold responses, responding abruptly only beyond a critical value of disturbance ${ }^{52}$. Surprisingly, the altered microbial communities re-established an alternative stable state in Luoma and Dongping lakes, but the stability reduced in Nansi Lake in stage two of water diversion. The results indicate that the phytoplankton in circular lakes had quicker responses and recoveries to the water transfer than phytoplankton in strip-shaped lakes. We guess that the stability of the phytoplankton community in Nansi Lake will also eventually recover in the future with continuation of the water transfer process, and we will conduct persistent monitoring and observation on the three lakes to check this.

Phytoplankton diversity in the lakes includes a range of functional groups, which play critical roles in transferring energy across the food web ${ }^{14-15}$. Therefore, tracking changes in the structure and diversity of algal groups is the key to characterising ecosystem function and measuring the impacts of disturbances. Despite the diversity of algal communities in the three lakes, there were certain consistent changes following water importation: surprisingly, the diversity and evenness of all, abundant and rare algae exhibited no dramatic changes in the three lakes after the disturbance of water diversion (Fig. 5, Fig. S8- S9). This result was not consistent with the studies of Yang et al. ${ }^{54}$ and Dai et al. ${ }^{55}$, where phytoplankton community diversity and evenness index were 
increased in Gonghu Bay when it was affected by water diversion. Importantly, their finding related to the effect of water diversion on community diversity mainly focused on short-term changes (i.e. over several months). Moreover, we can guess that the change in disturbed community diversity was affected by the sensitivity of the respective community to environmental change.

Whether the community structure would change irreversibly in response to disturbance is a current concern that needs to be solved. Tromas et al. viewed cyanobacterial blooms as a biological disturbance, quantified by their impact on the surrounding microbial community, and found that the community changes cyclically over the course of a year, with a repeatable pattern from year to year ${ }^{56}$. In our study, the algal composition became more and more similar to that in 2014 (the state directly after water diversion) during the long-term period of observation in the three lakes (Fig. 6, Fig. S10-S11). This could reflect resilience that allows the altered microbial community to recover to its original state or establish an alternative state after a disturbance ${ }^{44-45}$. With different consequences caused by disturbance, community structures affected by algal blooms are restored to their original status after a short period, while the communities affected by water diversion only stabilize to a new state; the differences in the recovery time and state could depend upon differences in the disturbance intensity and type.

The community compositions, particularly for abundant algae, were dissimilar in the three lakes, the main contributions to these distinct compositions in 2011 were the high abundances of Pseudanabaena limnetica (42.5\%), Chroomonas acuta (30.7\%) and Chlorella vulgaris (24.0\%) in respectively Luoma, Nansi and Dongping lakes; in 2012 Pseudanabaena limnetica (54.0\% in Luoma lake and $19.3 \%$ in Nansi lake) and Chroomonas acuta (27.9\% in Dongping lake) were dominant algal species in different lakes; and in 2013 Pseudanabaena limnetica (34.8\%), Chlorella vulgaris (24.0\%) and Chroomonas acuta (30.7\%) had the highest abundances in Luoma, Nansi and Dongping lakes, respectively. Meanwhile, no species homogenization across the lakes occurred after water diversion. The community compositions were distinct and there were different proportions of dominant algal species after water importation in the three lakes (Tables S2-S7). Unsurprisingly, this phenomenon was also found between two different lakes that were connected by water transfer (Fig. S10-S11). Contradictory conclusions have been reported that water diversion projects would lead to a massive introduction of distinct biodiversity in lakes, bio-invasion of lakes, and biotic homogenization across lakes ${ }^{12}$. Guo et al. investigated the influence of a water diversion project on fish communities and identified that increased hydrological connectivity had potentially created an "invasion highway" and promoted a potential biotic homogenization among the impounded lakes ${ }^{29}$. In a more comprehensive investigation, a wide variety of aquatic organisms (molluscs, zooplankton, crustaceans, insects, fish, amphibians, reptiles, mammals, and plants) was studied and the fact that a water diversion project caused homogenization between lakes was similarly proved ${ }^{57}$. Previous research has mainly focused on the effect of water transfer on aquatic plants and animals. Compared with plants and animals, diverted phytoplankton had more sensitive responses to environmental change (e.g. the change in nutrient levels within the three lakes), and our finding eliminated the concern that water diversion can cause phytoplankton homogeneity across different lakes.

\section{Conclusions}

Our 9 years of data provide empirical evidence that total algal density - particularly for cyanobacteria - in the three lakes exhibited a decrease in 2014 and remained unchanged for the next several years under the influence of the water diversion project; the concentrations of TN and TP also decreased after water transfer in all three lakes. Abundant and rare species were affected differently by water importation, with some rare species being transformed into abundant taxa, while the main abundant algae were almost unaffected by water diversion. In addition, we analysed phytoplankton data from the three lakes and found that greater differences in phytoplankton community composition were shown before and after water importation, and as the planned water transfer continued over the long term the algal community structure became similar to that in 2014 (the initial state after water diversion); surprisingly, there was no homogeneity in the algal compositions across different lakes after water diversion. Moreover, more stable phytoplankton communities occurred in non-water-diversion months than during water-diversion months, revealing that water mixing does have negative effects on the stability of community structure. The community stability decreased in Luoma and Dongping lakes in stage one, while it returned to its original level in stage two; conversely, the stability in Nansi Lake exhibited no obvious changes in stage one but decreased in stage two, speculating that the inconsistent responses of phytoplankton community stability to water diversion might be attributable to the different shapes of the lakes.

\section{Materials And Methods}




\subsection{Study areas, sampling and water quality data acquisition}

The eastern route of the South-to-North Water Diversion intersects with or directly passes through four large freshwater lakes in Jiangsu and Shandong provinces (i.e. Hongze Lake, Luoma Lake, Nansi Lake, and Dongping Lake). Because of the small amount of water that passed through Hongze Lake as part of the water diversion project during the study period (Table S1), the effect of water diversion on phytoplankton in Hongze Lake was not studied. The field sampling was conducted in Luoma Lake $\left(34^{\circ} 0^{\prime}-\right.$ $\left.34^{\circ} 14^{\prime} \mathrm{N}, 118^{\circ} 5^{\prime}-118^{\circ} 19^{\prime} \mathrm{E}\right)$, which is located in Jiangsu province, Nansi Lake $\left(34^{\circ} 27^{\prime}-35^{\circ} 20^{\prime} \mathrm{N}, 116^{\circ} 34^{\prime}-117^{\circ} 21^{\prime}\right.$ E) and Dongping Lake $\left(35^{\circ} 30^{\prime}-36^{\circ} 20^{\prime} \mathrm{N}, 116^{\circ} 00^{\prime}-116^{\circ} 30^{\prime} \mathrm{E}\right)$, which are located in Shandong province, China (Fig. 7). The three lakes, which belong to the eastern route of the South-to-North Water Diversion Project, are important drinking water sources for the inhabitants of Jiangsu and Shandong provinces. For Luoma, Nansi and Dongping lakes there were respectively six sampling sites (Yanghetan, Zaohe, Huquzhong1, Huquzhong2, Huqudong and Huquxi), five sites (Qianbaikou, Nanyang, Erjiba, Dajuan, and Daodong) and three sites (Hunan, Huxin and Hubei) (Fig. 7). Luoma, Nansi and Dongping lakes first officially transferred water in October 2013, and water diversion is executed according to the national water diversion plan, with the precise water transfer period each year being distinct for each lake (Fig. S1). The main characteristics of the three studied lakes are presented in Table S12.

Sampling was conducted every month from March 2011 to December 2019 across all of the sampling locations in Luoma, Nansi and Dongping lakes. Each station was sampled using a Ruttner water sampler (Hydrobios, Germany, $1 \mathrm{~L}$ ). Within each sampling site, $3 \mathrm{~L}$ of water samples were collected for chemical analyses and $1 \mathrm{~L}$ for phytoplankton identi $\square$ cation and counting. Water for chemical analyses was analysed within $48 \mathrm{~h}$ after sampling. Phytoplankton communities were $\square x e d$ with $1.5 \%$ Lugol's iodine solution in situ and stored in the dark. Water temperature (WT), dissolved oxygen concentration (DO), transparency (Trans) and pH were measured using on-site instruments. A thermometer (TES1316, Shanghai Precision Instruments Co., China), portable DO meter (HQ30d, Hach, USA), Secchi disc $(20 \mathrm{~cm})$, and portable pH meter (FE28, Mettler Toledo, China) were used, respectively. Concentrations of total nitrogen (TN), total phosphorus (TP), and ammonia nitrogen $\left(\mathrm{NH}_{3}-\mathrm{N}\right)$ were analysed according to the Standard Methods for the Examination of Water and Wastewater ${ }^{58}$. The chemical oxygen demand $\left(\mathrm{COD}_{\mathrm{Mn}}\right)$ was determined by an acidic potassium permanganate method ${ }^{58}$. The values for each of the sampling stations were obtained through three parallel subsamples.

\subsection{Phytoplankton data}

Analysis of algae involved sample concentration through two settling steps: firstly, from an original volume of $1 \mathrm{~L}$ to $50 \mathrm{~mL}$ (settling time was 24 hours), and then to a final volume of $10 \mathrm{~mL}$ (settling time was also 24 hours). Thereafter phytoplankton characterization was undertaken using a microscope (CX41, Olympus, Japan) with 400x magnification for at least 200 units (single cells, colonies and filaments). Taxonomic identification of the phytoplankton species was done according to some international websites, such as "NBN atlas" and "WoRMS", and one book, "Freshwater Algae in China (System, Classification and Ecology)".

\subsection{Definitions of abundant and rare taxa}

The definitions of abundant and rare taxa depend on the cut-off level of relative abundance, as previously reported ${ }^{41}$. All algal species were classified into one of six categories: always abundant taxa; conditionally abundant taxa; always rare taxa; conditionally rare taxa; moderately abundant taxa; and conditionally rare and abundant taxa. The abundant taxa consist of always abundant and conditionally abundant taxa, and the rare taxa include always rare and conditionally rare taxa. A detailed description of abundant and rare phytoplankton data is shown in Tables S2-S7.

\subsection{Relationship between phytoplankton community composition and environment variables}

The Mantel test using the "vegan" package in R was implemented to select signi $\square$ cant environmental factors correlated with the variations of all, abundant, and rare phytoplankton communities. Prior to the analysis, the normality of the physicochemical variables was checked using the Shapiro-Wilk test, and $\log (x+1)$ transformed, with the exception of $\mathrm{pH}$, to improve normality and homoscedasticity ${ }^{46}$.

\subsection{The similarity of phytoplankton community composition}


Natural patterns of phytoplankton community similarity were examined using clustering analyses and multivariate ordinations to find breakpoints in community composition states. The Bray-Curtis dissimilarity matrix was constructed from square-roottransformed data for each algal species at every time point. This was accomplished using the "vegan" and "pvcluster" packages 59 in the R environment for statistical computing ${ }^{60}$.

\subsection{Construction and characterization of co-occurrence networks}

Co-occurrence networks were used to summarize the impact of dominance by a limited number of algal species on the structure of phytoplankton communities ${ }^{61-62}$. Phytoplankton communities were analysed using this approach in order to clarify the network characteristics during water-diversion months, during non-water-diversion months, and at different stages of water diversion in different lakes. Co-occurrence networks from each group were constructed using algal species with relative abundances of more than $0.2 \%$, which corresponds to a compromise between the need to keep algae with a high number of observations to accurately estimate their co-occurrence and the need to keep enough algal species in the analysis to construct networks that are representative of the communities observed in the $\square e d^{63}$. Subsequently all possible pairwise Spearman's rank correlations $(r)$ between those species were calculated within the " $p s y c h$ " R package. Only robust $(r>|0.5|)$ and statistically signi』cant $(p$-value < $0.05)$ correlations were incorporated in the network analysis. Network visualization and modular analyses were performed with Gephi (version 0.9.2).

Networks are composed of nodes, which correspond to individual algal species, connected by links (or edges), that represent significant associations between nodes. Network density reflects a network's complexity and corresponds to the ratio between realized and potential links. The clustering coefficient was used to describe to what extent a node was connected with its neighbours.

\section{Declarations}

\section{Acknowledgements}

This work was supported by the Natural Science Foundation of China (51878386). We thank Dr. David Verrelli (Division One Academic and Language Services) and co-workers well educated in academic English to edit the grammar and language.

\section{Competing interests}

The authors declare no competing interests.

\section{References}

1. Long, D., Yang, W.T., Scanlon, B.R., Zhao, J.S., Liu, D.G., Burek, P., Pan, Y., You, L.Z., Wada, Y., 2020. South-to-North Water Diversion stabilizing Beijing's groundwater levels. Nat. Commun., 11, 3665.

2. Mekonnen, M. M., Hoekstra, A. Y., 2016. Four billion people facing severe water scarcity. Sci. Adv., 2(2), e1500323.

3. Boretti, A., Rosa, L., 2019. Reassessing the projections of the World Water Development Report. NPJ Clean Water, 2, 15.

4. 2008. A fresh approach to water. Nature. 452(7185), 253.

5. 2003. How to slake a planet's thirst. Nature, 422(6929), 243.

6. Liu, J.G., Yang, W., 2012. Water sustainability for China and beyond. Science, 337, 649-650.

7. Oki, T., Kanae, S., 2006. Global hydrological cycles and world water resources. Science. 313, 1068-1072.

8. Yu, M., Wang, C., Liu, Y., Olsson, G., Wang, C. 2017. Sustainability of mega water diversion projects: experience and lessons from china. Sci. Total Environ., 619-620, 721-731.

9. Darrow, G., 1972. Water importation. Science, 176(4039), 1071-1072.

10. Nong, X.Z., Shao, D.G., Zhong, H., Liang, J.K., 2020. Evaluation of water quality in the South-to-North Water Diversion Project of China using the water quality index (WQI) method. Water Res., 178, 115781. 
11. Zhang, X.L., Zou, R., Wang, Y.L., Liu, Y., Zhao, L., Zhu, X., Guo, H.C., 2016. Is water age a reliable indicator for evaluating water quality effectiveness of water diversion projects in eutrophic lakes? J. Hydrobiol., 542, 281-291.

12. Simoes Vitule, J.R., Azevedo-Santos, V.M., Salete Daga, V., Pereira Lima-Junior, D., Barroso de Magalhaes, A.L., Orsi, M.L., Pelicice, F.M., Agostinho, Â.A., 2015. Brazil's drought: protect biodiversity. Science, 347(6229), 1427-1428.

13. Guo, C.B., Chen, Y.S., Li, W., Xie, S.G., Lek, S., Li, Z.J., 2018. Food web structure and ecosystem properties of the largest impounded lake along the eastern route of China's South-to-North Water Diversion Project. Ecol. Inform., 43, 174-184.

14. Stockwell, J.D., Doubek, J.P., Adrian, R., Anneville, O., Carey, C.C., et al., 2020. Storm impacts on phytoplankton community dynamics in lakes. Global Change Biol., 26(5), 2756-2784.

15. Su, X.M., Steinman, A.D., Xue, Q.J., Zhao, Y.Y., Tang, X.M., Xie, L.Q.,2017. Temporal patterns of phyto- and bacterioplankton and their relationships with environmental factors in Lake Taihu, China. Chemosphere, 184, 299-308.

16. Aufdenkampe, A.K., Mayorga, E., Raymond, P.A., Melack, J.M., Doney, S.C., Alin, S.R., Aalto, R.E., Yoo, K., 2011. Riverine coupling of biogeochemical cycles between land, oceans, and atmosphere. Front. Ecol. Environ., 9, 53-60.

17. Moorhouse, H.L., Read, D.S., McGowan, S., Wagner, M., Roberts, C., Armstrong, L.K., Nicholls, D.J.E., Wickham, H.D., Hutchins, M.G., Bowes, M.J., 2018. Characterisation of a major phytoplankton bloom in the River Thames (UK) using flow cytometry and high performance liquid chromatography. Sci. Total Environ., 624, 366-376.

18. Guo, K., Wu, N.C., Wang, C., Yang, D.G., He, Y.F., Luo, J.B., Chai, Y., Duan, M., Huang, X.F., Riis, T., 2019. Trait dependent roles of environmental factors, spatial processes and grazing pressure on lake phytoplankton metacommunity. Ecol. Indic., 103, 312320.

19. Edmondson, W.T., 1970. Phosphorus, nitrogen, and algae in Lake Washington after diversion of sewage. Science, 169, 690691.

20. Lynch, M., Neufeld, J., 2015. Ecology and exploration of the rare biosphere. Nat. Rev. Microbiol., 13, $217-229$.

21. Martín, P.V., Buček, A., Bourguignon, T., Pigolotti, S., 2020. Ocean currents promote rare species diversity in protists. Sci. Adv., 6, eaaz9037.

22. Lennon, J.T., Jones, S.E., 2011. Microbial seed banks: the ecological and evolutionary implications of dormancy. Nat. Rev. Microbiol., 9, 119-130.

23. Liu, L., Yang, J., Yu, Z., Wilkinson, D. M., 2015. The biogeography of abundant and rare bacterioplankton in the lakes and reservoirs of China. ISME J., 9, 2068-2077.

24. Hines, J., Keil, P., 2020. Common competitors and rare friends. Nat. Ecol. Evol., 4(1), 8-9.

25. Saunders, Fenella. 2006. Going against the flow. Science, 313(5790), 1034-1037.

26. Tian, C., Pei, H., Hu, W., Xie, J., 2013. Phytoplankton variation and its relationship with the environmental factors in Nansi Lake, China. Environ. Monit. Assess., 185(1), 295-310.

27. Qu, X., Chen, Y.S., Liu, H., Xia, W.T., Lu, Y., G, D.D., Lin, L.S., 2020. A holistic assessment of water quality condition and spatiotemporal patterns in impounded lakes along the Eastern Route of China's South-to-North Water Diversion Project. Water Res., 185, 116275.

28. Liu, D.S., Wang, R., Gordon, D.R., Sun, X.H., Chen, L., Wang, Y.W. 2017. Predicting plant invasions following China's water diversion project. Environ. Sci. Technol., 51(3), 1450.

29. Guo, C.B., Chen, Y.S., Gozlan, R. E., Liu, H., Lu, Y., Qu, X., Xia, W.T., Xiong F.Y., Xie, S.G., Wang, L.Z., 2020. Patterns of fish communities and water quality in impounded lakes of China's South-to-North Water Diversion Project. Sci. Total Environ., 713, 136515.

30. Pan, Y., Yuan, Y., Sun, T., Wang, Y., Fan, Z., 2020. Are the water quality improvement measures of China's South-to-North Water Diversion Project effective? A case study of Xuzhou section in the east route. Int. J. Environ. Res. Public Health, 17(17), 6388.

31. Plaxton, W. C., Lambers, Hans., 2015. Chapter 12. Algae in a phosphorus-limited landscape. Annual Plant Reviews. Volume 48: Phosphorus Metabolism in Plants. John Wiley \& Sons, Inc.

32. Elser, J.J., Bracken, M.E.S., Cleland, E.E., Gruner, D. S., Harpole, W. S., Hillebrand, H., Ngai, J.T., Seabloom, E.W., Shurin, J.B., Smith, J.R., 2007: Global analysis of nitrogen and phosphorus limitation of primary producers in freshwater, marine and terrestrial ecosystems. Ecol. Lett., 10, 1135-1142.

Page $10 / 18$ 
33. Hu, T.T., Liu J.S., Dai X.L., Cai Y.J., Xu H., Gong Z.J., 2016. Spatio-temporal variation of water quality in Lake Luoma, Jiangsu Province, China. Journal of Ecology and Rural Environment, 32, 794-801.

34. Moss, B.; Jeppesen, E.; Søndergaard, M.; Lauridson, T. L.; Liu, Z., 2013. Nitrogen, macrophytes, shallow lakes and nutrient limitation: resolution of a current controversy? Hydrobiol., 710, 3-21.

35. Paerl, H. W., Scott, J. T., McCarthy, M. J., Newell, S. E., Gardner, W. S., Havens, K. E., Hoffman, D.K., Wilhelm, S.W., Wurtsbaugh, W.A., 2016. It takes two to tango: when and where dual nutrient (N \& P) reductions are needed to protect lakes and downstream ecosystems. Environ. Sci. Technol., 50(20), 10805-10813.

36. Paerl, H.W., 2008. Nutrient and other environmental controls of harmful cyanobacterial blooms along the freshwater-marine continuum. Adv. Exp. Med. Biol., 619, 216-241.

37. Huisman, J., 2018. Cyanobacterial blooms. Nature, 16, 471-483.

38. Rousso, B. Z., Bertone, E., Stewart, R., Hamilton, D. P., 2020. A systematic literature review of forecasting and predictive models for cyanobacteria blooms in freshwater lakes. Water Res., 182, 115959.

39. Olson, N. E., Cooke, M. E., Shi, J. H., Birbeck, J. A., Ault, A. P., 2020. Harmful algal bloom toxins in aerosol generated from inland lake water. Environ. Sci. Technol., 54(8), 4769-4780.

40. Paerl, H.W., Huisman, J., 2008. Climate: blooms like it hot. Science, 320, 57-58.

41. Logares, R., Audic, S., Bass, D., Bittner, L., Boutte, C., Christen, R., Claverie, J.M., Decelle, J., Dolan, J.R., Dunthorn, M., 2014. Patterns of rare and abundant marine microbial eukaryotes. Curr. Biol., 24, 813-821.

42. Pedrós-Alió, C., 2012. The rare bacterial biosphere. Ann Rev Mar Sci., 4, 449-466.

43. Jiao, S., Luo, Y.T., Lu, M.M., Xiao, X., Lin, Y.B., Chen, W.M., Wei, G.H., 2017. Distinct succession patterns of abundant and rare bacteria in temporal microcosms with pollutants. Environ. Pollut., 225, 497-505.

44. Griffiths, B.S., Philippot, L., 2013. Insights into the resistance and resilience of the soil microbial community. FEMS Microbiol. Rev., 37, 112-129.

45. Hodgson, D., McDonald, J.L., Hosken, D.J., 2015. What do you mean, 'resilient'? Trends Ecol. Evol., 30, 503-506.

46. Xue, Y.Y., Chen, H.H., Yang, J.R., Liu, M., Huang, B.Q., Yang, J., 2018. Distinct patterns and processes of abundant and rare eukaryotic plankton communities following a reservoir cyanobacterial bloom. ISME J., 12, 2263-2277.

47. Campbell, B.J., Yu, L., Heidelberg, J.F., Kirchman, D.L., 2011. Activity of abundant and rare bacteria in a coastal ocean. P. Natl. Acad. Sci. USA., 108(31), 12776.

48. Treusch, A.H., Vergin, K.L., Finlay, L.A., Donatz, M.G., Giovannoni, S.J. 2009. Seasonality and vertical structure of microbial communities in an ocean gyre. ISME J., 3(10), 1148-1163.

49. Zhang, H., Hou, F., Xie, W., Wang, K., Zhou, X., Zhang, D., et al. 2020. Interaction and assembly processes of abundant and rare microbial communities during a diatom bloom process. Environ. Microbiol., 22(5), 1707-1719.

50. Naselli-Flores, L., Barone, R., 2000. Phytoplankton dynamics and structure: a comparative analysis in natural and man-made water bodies of different trophic state. Hydrobiol., 438, 65-74.

51. O’Farrell, I., Izaguirre, I., Chaparro, G., Sinistro, R., Pizarro, H., Rodríguez, P., de Tezanos Pinto, P., Lombardo, R., Tell, G., 2011. Water level as the main driver of the alternation between a free-floating plant and a phytoplankton dominated state: a longterm study in a floodplain lake. Aquat. Sci., 73, 275-287.

52. Narwani, A., Reyes, M., Pereira, A.L., Penson, H., Matthews, B., 2019. Interactive effects of foundation species on ecosystem functioning and stability in response to disturbance. Proceedings of the Royal Society B: Biological Sciences, 286(1913), 20191857.

53. Douterelo, I., Dutilh, B.E., Arkhipova, K., Calero, C., Husband, S., 2020. Microbial diversity, ecological networks and functional traits associated to materials used in drinking water distribution systems. Water Res., 173, 115586.

54. Yang, Q.Q., Wu, S.Q., Dai, J.Y., Wu, X.F., Xue, W.Y., Liu, F., 2018. Effects of short-term water diversion in summer on water quality and algae in Gonghu Bay, Lake Taihu. J. Lake Sci., 30(1), 34-43.

55. Dai, J., Wu, S., Wu, X., Lv, X., Sivakumar, B. 2020. Impacts of a large river-to-lake water diversion project on lacustrine phytoplankton communities. J. Hydrol., 587, 124938.

Page $11 / 18$ 
56. Tromas, N., Fortin, N., Bedrani, L., Terrat, Y., Cardoso, P., Bird, D., et al. 2017. Characterising and predicting cyanobacterial blooms in an 8-year amplicon sequencing time course. ISME J., 11, 1746-1763.

57. Daga, V.S., Azevedo-Santos, V.M., Pelicice, F.M., Fearnside, P.M., Perbiche-Neves, G., Paschoal, L., et al. 2020. Water diversion in Brazil threatens biodiversity. Ambio, 49, 165-172.

58. China, M., 2002. Standard Methods for the Examination of Water and Wastewater (Version 4). China Environmental Science Press, Beijing, China.

59. Suzuki, R., Shimodaira, H., 2015. pvclust: Hierarchical Clustering with $P$-Values via Multiscale Bootstrap Resampling. R package version 2.0-0. Retrieved from http://CRAN.R-project.org/package=pvclust.

60. R Core Team., 2015. R: a Language and Environment for Statistical Computing. Vienna, Austria: R Foundation for Statistical Computing. Retrieved from http://www.r-project.org/

61. Mendez, G,L., Faust, K., Henry, N. et al., 2015. Determinants of community structure in the global plankton interactome. Science, 348, 1262073.

62. Guidi, L., Chaffron, S., Bittner, L. et al. 2016. Plankton networks driving carbon export in the oligotrophic ocean. Nature, 532, 465-470.

63. Escalas, A., Catherine, A., Maloufi, S., Cellamare, M., Hamlaoui, S., Yéprémian, C., Louvard, C., Troussellier, M., Bernard, C., 2019. Drivers and ecological consequences of dominance in periurban phytoplankton communities using networks approaches. Water Res., 163, 114893.

\section{Tables}

Table 1. Spearman correlations of the phytoplankton communities with environmental factors based on Mantel tests.

\begin{tabular}{|c|c|c|c|c|c|c|c|c|c|}
\hline \multirow[b]{2}{*}{$\begin{array}{l}\text { Environmental } \\
\text { factor }\end{array}$} & \multicolumn{3}{|c|}{ Luoma Lake } & \multicolumn{3}{|c|}{ Nansi Lake } & \multicolumn{3}{|c|}{ Dongping Lake } \\
\hline & All & Abundant & Rare & All & Abundant & Rare & All & Abundant & Rare \\
\hline Temperature & $0.321 * *$ & $0.044 *$ & 0.035 & $0.149 * *$ & $0.112 * *$ & -0.009 & $0.112 * *$ & $0.087 * *$ & -0.033 \\
\hline $\mathrm{pH}$ & $0.083^{*}$ & $0.158 * *$ & $0.418^{* *}$ & $0.071 *$ & $0.073^{*}$ & $0.106 * *$ & -0.026 & -0.010 & -0.057 \\
\hline Transparency & $0.130 * *$ & 0.033 & -0.034 & -0.096 & -0.092 & -0.116 & $0.177 * *$ & $0.158 * *$ & $0.265^{* *}$ \\
\hline $\begin{array}{l}\text { Dissolved } \\
\text { oxygen }\end{array}$ & $0.281 * *$ & $0.087 * *$ & $0.077^{*}$ & 0.028 & 0.013 & 0.007 & -0.066 & -0.062 & -0.121 \\
\hline $\mathrm{COD}_{\mathrm{Mn}}$ & -0.026 & -0.025 & 0.034 & 0.066 & 0.054 & 0.075 & $0.283^{* *}$ & $0.265^{* *}$ & $0.441^{* *}$ \\
\hline $\begin{array}{l}\text { Ammonia } \\
\text { nitrogen }\end{array}$ & 0.059 & 0.108* & $0.372 * *$ & $0.122 * *$ & $0.124 * *$ & $0.222 * *$ & $0.291 * *$ & $0.230 * *$ & $0.432 * *$ \\
\hline Total nitrogen & $0.106^{* *}$ & $0.161 * *$ & $0.250 * *$ & $0.224 * *$ & $0.248 * *$ & $0.324 * *$ & $0.353 * *$ & $0.335^{* *}$ & $0.453^{* *}$ \\
\hline $\begin{array}{l}\text { Total } \\
\text { phosphorus }\end{array}$ & 0.041 & -0.029 & -0.024 & $0.377 * *$ & $0.383^{* *}$ & $0.610 * *$ & -0.024 & -0.047 & -0.029 \\
\hline $\mathrm{N} / \mathrm{P}$ ratio & $0.139 * *$ & $0.111 *$ & $0.257 * *$ & $0.157 * *$ & $0.169 * *$ & $0.215^{* *}$ & $0.216^{* *}$ & $0.208 * *$ & $0.288 * *$ \\
\hline
\end{tabular}

"All" denotes the entire phytoplankton community; "Abundant" denotes abundant species in the phytoplankton community; "Rare" denotes rare species in the phytoplankton community.

The significances are tested based on 999 permutations, and bold values indicate statistically significant correlation: “*” denotes $p<0.05$, and “**” denotes $p<0.01$.

\section{Figures}


Luoma Lake

Nansi Lake

Dongping Lake

Afler water diversion

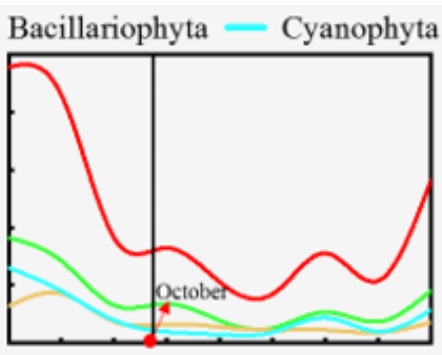

Total algae
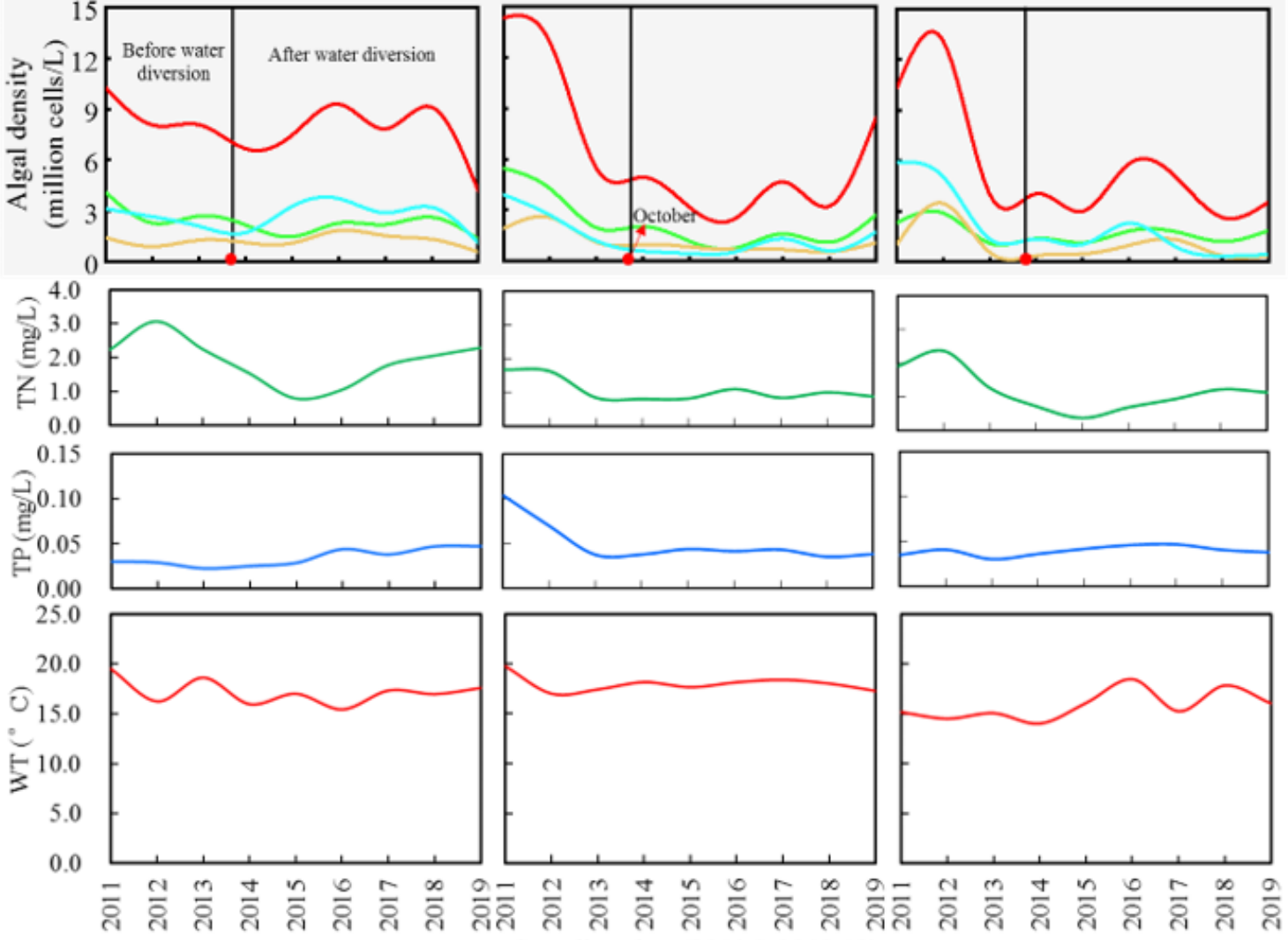

Sampling date (2011.3-2019.12)

\section{Figure 1}

Interannual variation of phytoplankton abundance and water quality characteristics (TN, TP and WT) in Luoma, Nansi and Dongping lakes. The figures demonstrate total algae density decreased after water diversion in three lakes especially in Nansi Lake and Dongping Lake. 


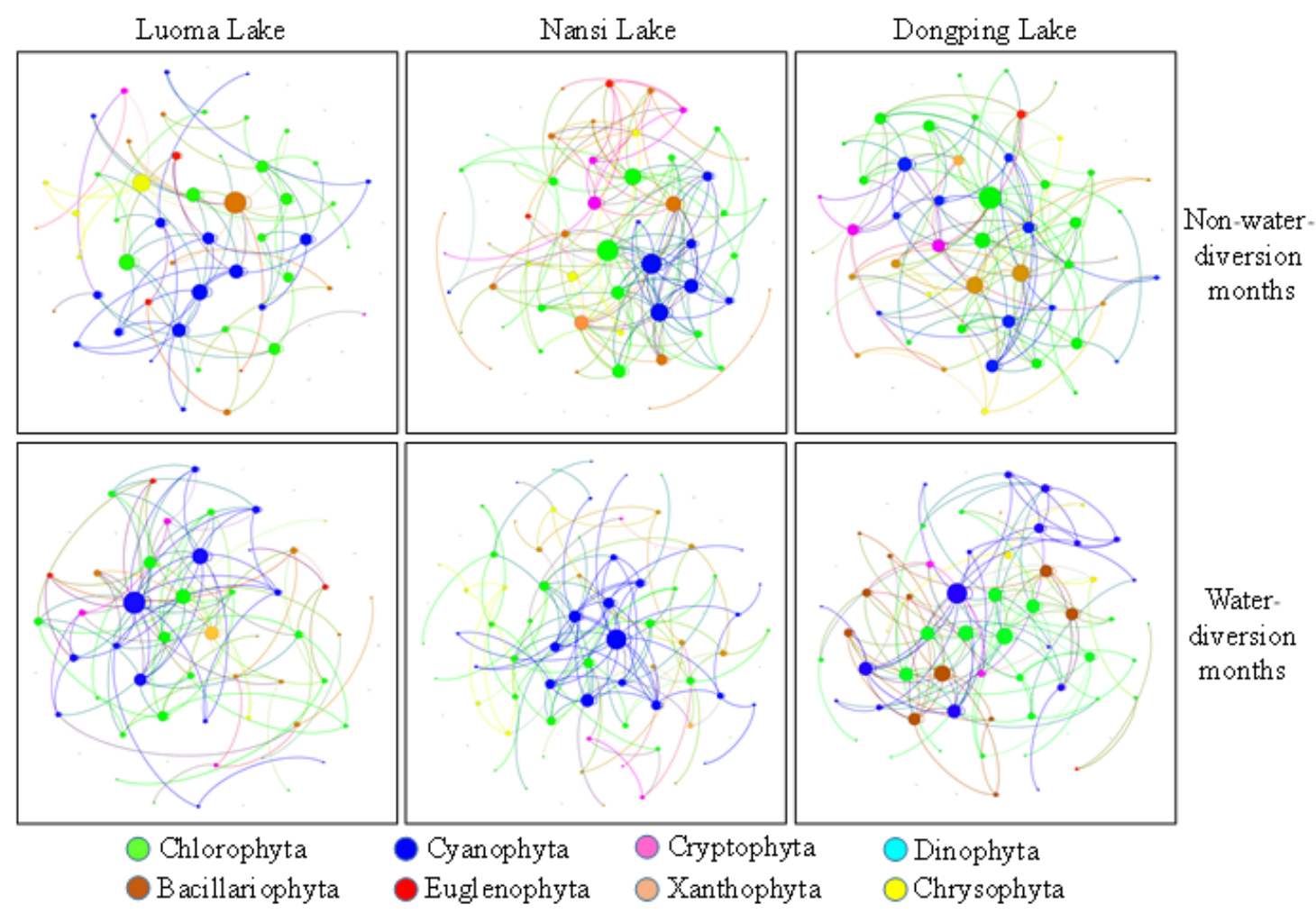

Figure 2

Structures of phytoplankton co-occurrence networks and algal communities were more stable during non-water-diversion months than water-diversion months in three lakes. Nodes correspond to phyla and links correspond to statistically significant associations. Nodes are coloured according to their taxonomy. A node's size represents the strength of the links in the communities comprising their network. 


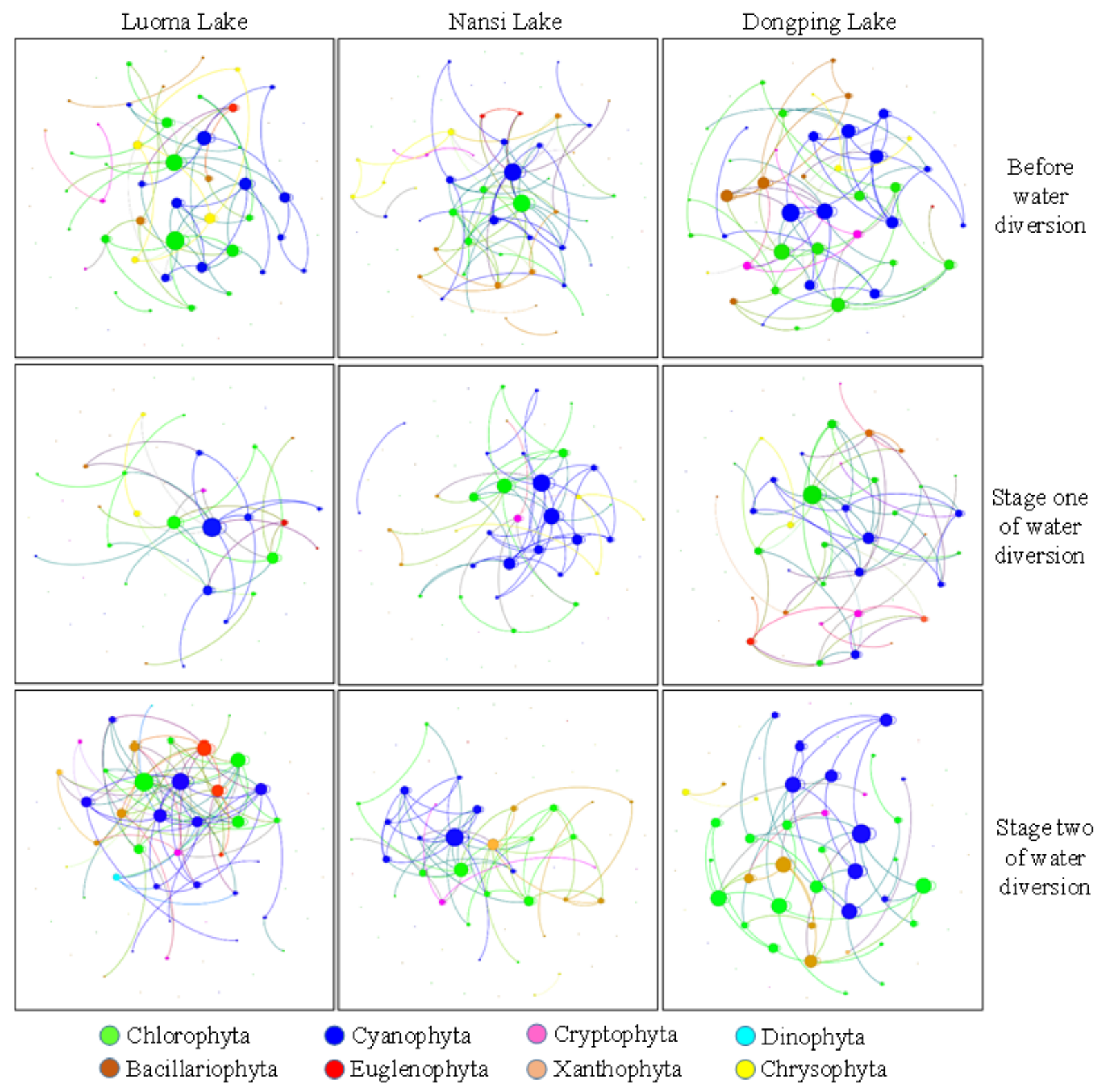

Figure 3

The stability of algal communities reverted at stage two of water diversion in Luoma and Dongping lakes, while deteriorated in Nansi Lake. Nodes correspond to phyla and links correspond to significant associations. Nodes are coloured according to their taxonomy. A node's size represents the strength of the links in the communities comprising their network. 

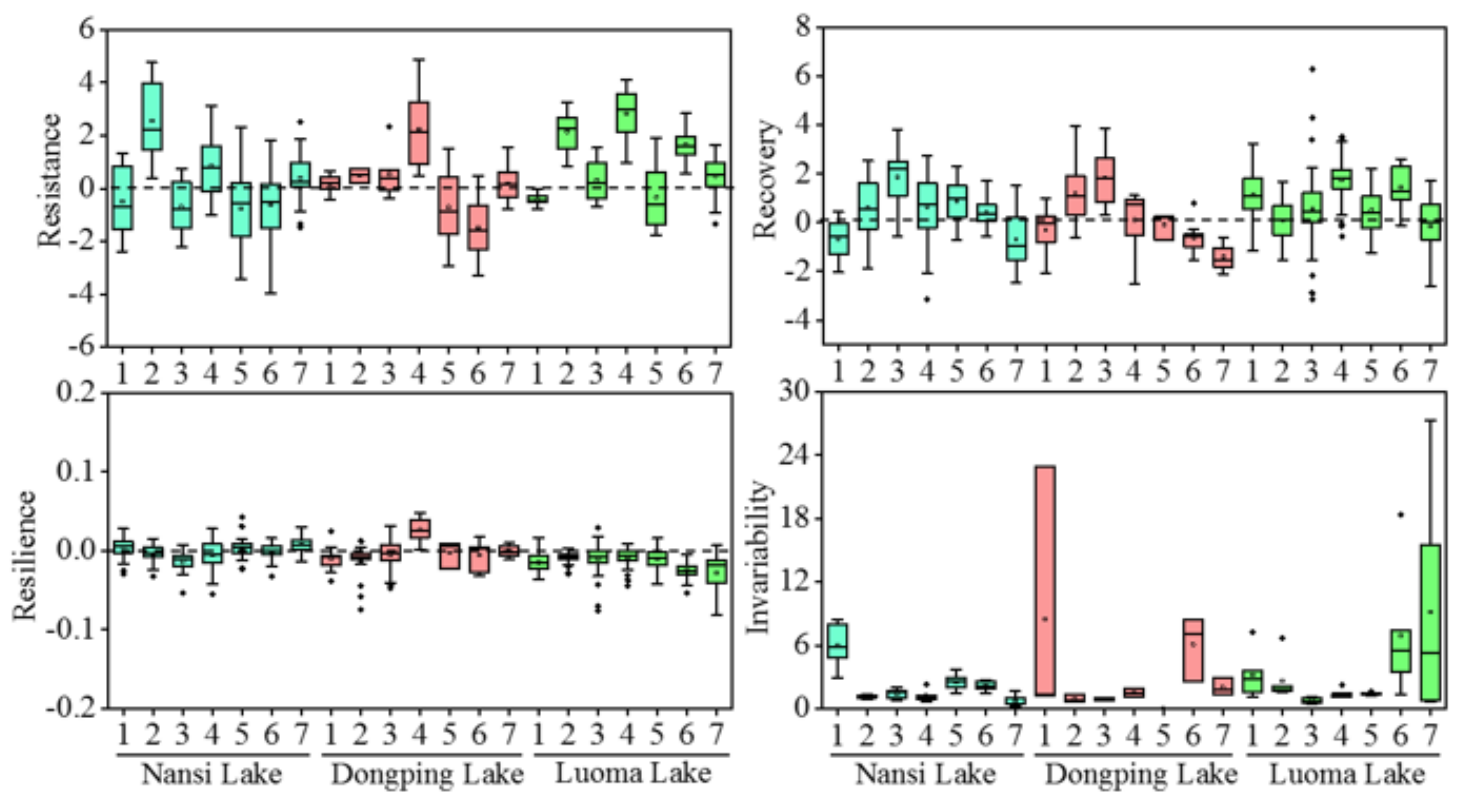

\section{Figure 4}

The four dimension of stability (resistance, recovery, resilience and invariability) responded to seven-times intermittent water diversion disturbances among three lakes.
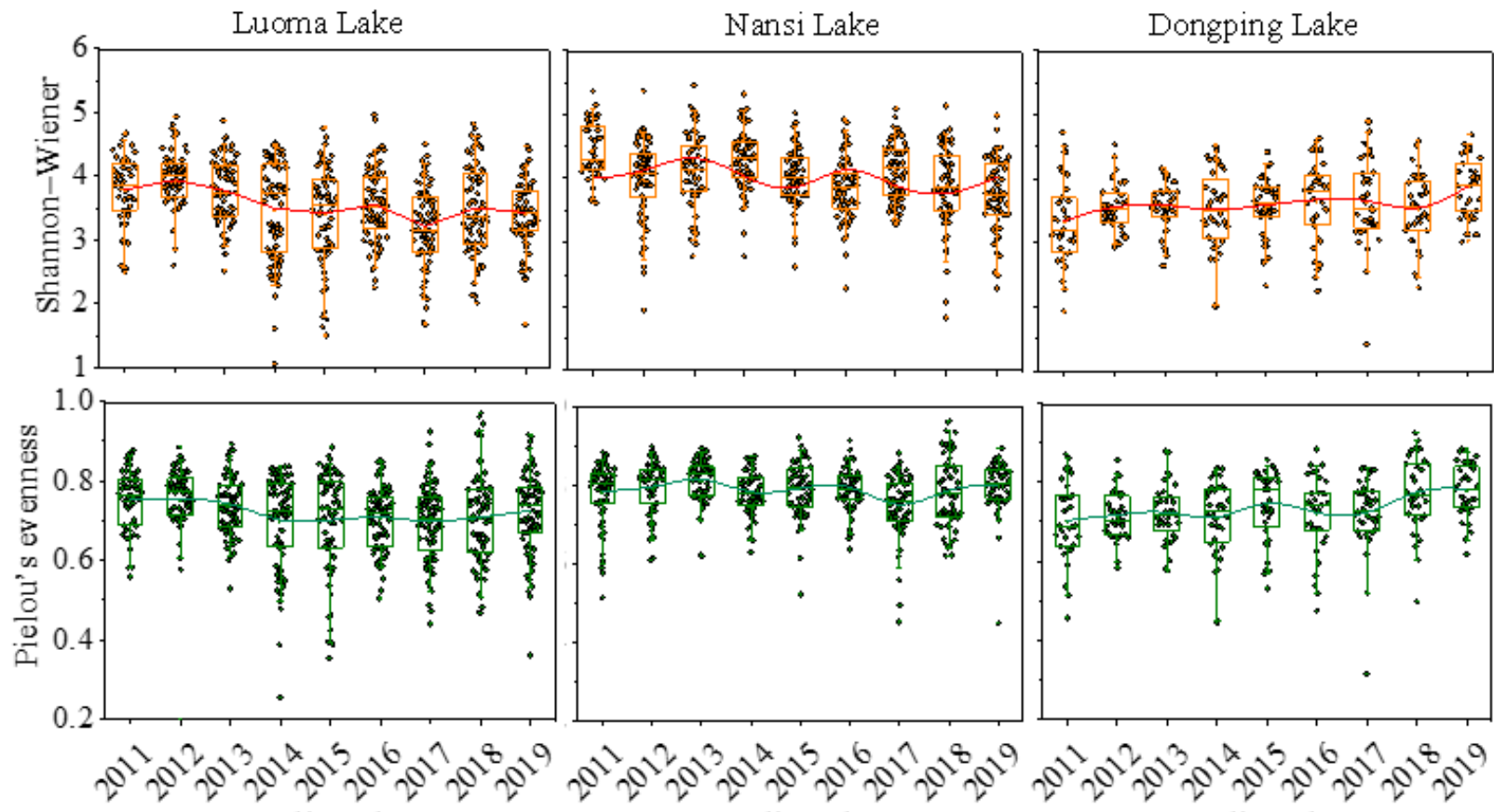

Sampling date

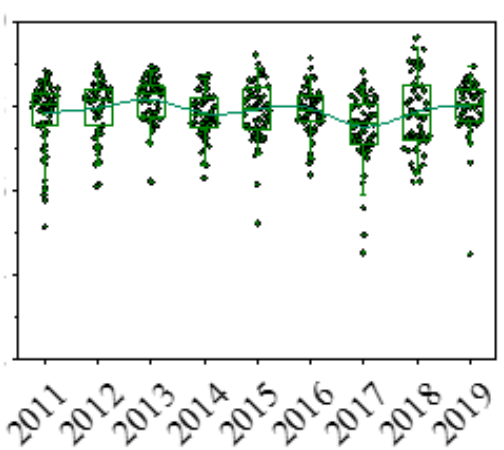

Sampling date

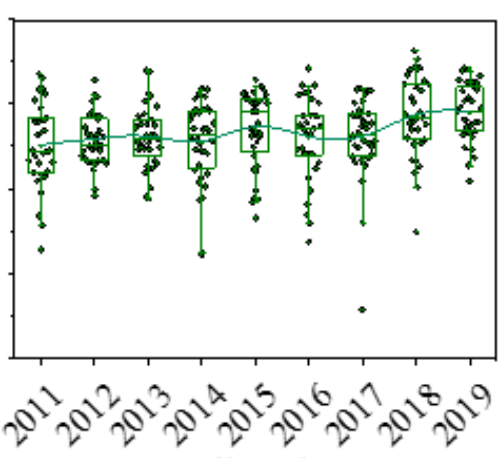

Sampling date

\section{Figure 5}

Alpha diversity of all phytoplankton and water transfer had no obvious effect on community diversity and evenness within different lakes. The solid line denotes the fitting line of the average values. 

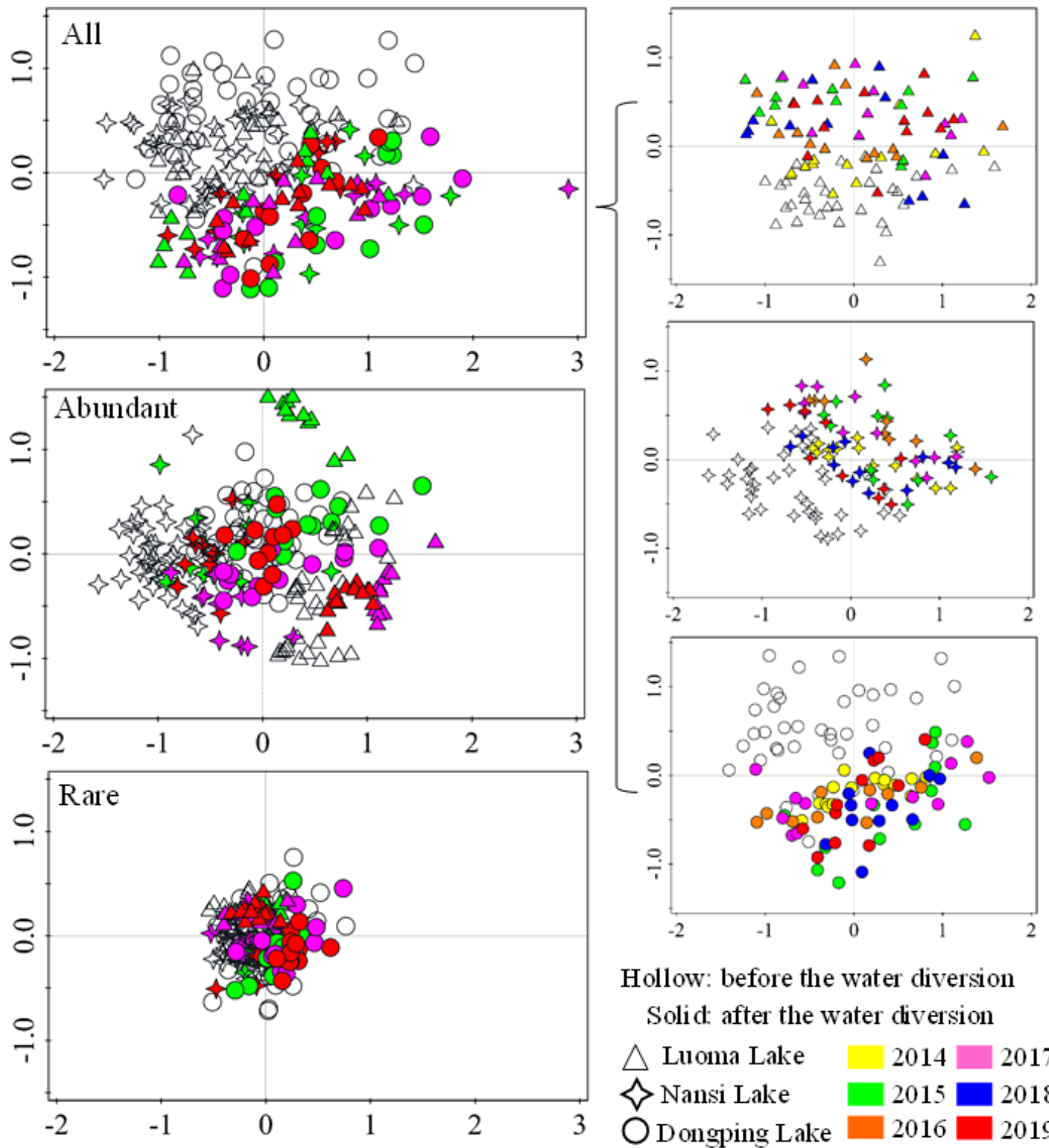

Hollow: before the water diversion Solid: after the water diversion

\begin{tabular}{lll|l}
$\triangle$ Luoma Lake & 2014 & 2017 \\
๖ Nansi Lake & 2015 & 2018 \\
OD Dongping Lake & 2016 & 2019
\end{tabular}

Figure 6

Water diversion cannot cause homogenization of algal communities across three lakes and algal communities were similar to that in 2014 with long-term intermittent water diversion. Each point in the NMDS plot represents a sample, with distances between samples calculated as a measure of community composition. Different shapes represent different lakes. Unfilled symbols represent samples before water diversion, and filled symbols represent samples after water diversion. 


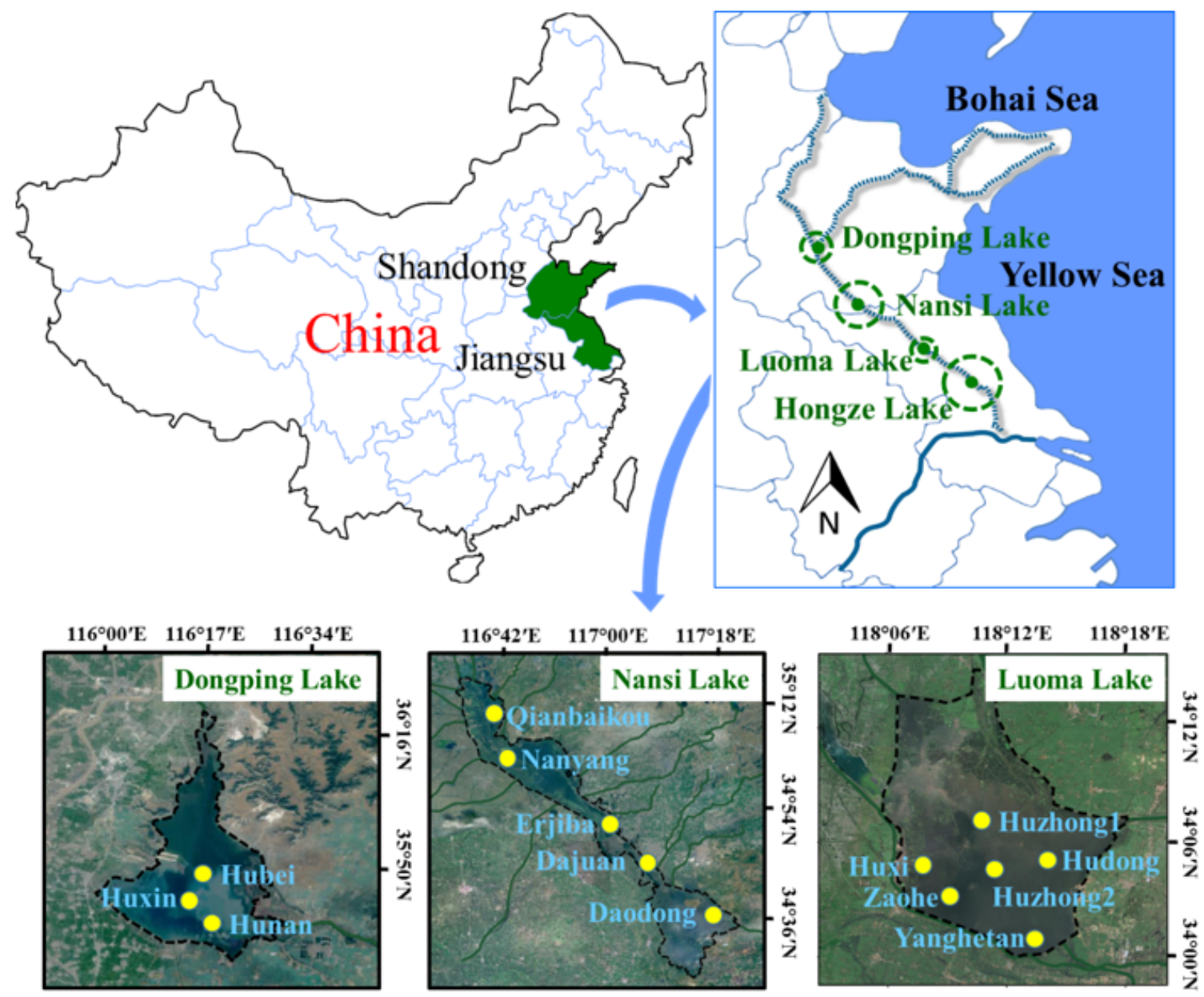

Figure 7

Geographic locations of sampling stations. The size of each dashed circle represents the relative lake surface area. Hongze Lake located on the eastern route of the South-to-North Water Diversion Project, while was not selected to verify the effect of water diversion on phytoplankton communities, as the amount of water diverted annually through it is relatively small, or even nil, in most monitoring years.

\section{Supplementary Files}

This is a list of supplementary files associated with this preprint. Click to download.

- Supplementarymaterials.docx 